OPEN ACCESS

Edited by:

Jennifer Straughen,

Henry Ford Health System,

United States

Reviewed by:

Maurizio Elia,

Oasi Research Institute (IRCCS), Italy

Andrea De Giacomo,

University of Bari Aldo Moro, Italy

${ }^{*}$ Correspondence:

Evelyn Xiu Ling Loo

evelyn_10o@sics.a-star.edu.sg

†These authors share first authorship

Specialty section:

This article was submitted to

Pediatric Neurology,

a section of the journal

Frontiers in Neurology

Received: 07 September 2020 Accepted: 30 December 2020

Published: 15 February 2021

Citation:

Chua RXY, Tay MJY, Ooi DSQ Siah KTH, Tham EH, Shek LP-C, Meaney MJ, Broekman BFP and Loo EXL (2021) Understanding the

Link Between Allergy and

Neurodevelopmental Disorders: A

Current Review of Factors and

Mechanisms.

Front. Neurol. 11:603571.

doi: 10.3389/fneur.2020.603571

\section{Understanding the Link Between Allergy and Neurodevelopmental Disorders: A Current Review of Factors and Mechanisms}

\author{
Regena Xin Yi Chua ${ }^{1 \dagger}$, Michelle Jia Yu Tay ${ }^{1 \dagger}$, Delicia Shu Qin Ooi ${ }^{1,2}$, Kewin Tien Ho Siah ${ }^{3,4}$, \\ Elizabeth Huiwen Tham ${ }^{1,2,5}$, Lynette Pei-Chi Shek ${ }^{1,2,5}$, Michael J. Meaney ${ }^{1,5,6}$, \\ Birit F. P. Broekman ${ }^{5,7}$ and Evelyn Xiu Ling Loo ${ }^{1,5 *}$ \\ ${ }^{1}$ Department of Pediatrics, Yong Loo Lin School of Medicine, National University of Singapore, Singapore, Singapore, ${ }^{2}$ Khoo \\ Teck Puat-National University Children's Medical Institute, National University Hospital, National University Health System, \\ Singapore, Singapore, ${ }^{3}$ Department of Medicine, Yong Loo Lin School of Medicine, National University of Singapore, \\ Singapore, Singapore, ${ }^{4}$ Division of Gastroenterology \& Hepatology, University Medicine Cluster, National University Hospital, \\ Singapore, Singapore, ${ }^{5}$ Singapore Institute for Clinical Sciences (SICS), Agency for Science, Technology and Research \\ (A*STAR), Singapore, Singapore, ${ }^{6}$ Ludmer Centre for Neuroinformatics and Mental Health and Department of Psychiatry, \\ McGill University, Montréal, QC, Canada, ${ }^{7}$ Department of Psychiatry, Onze Lieve Vrouwe Gasthuis and Amsterdam University \\ Medical Centre, VU University Medical Center, Amsterdam, Netherlands
}

Both allergic diseases and neurodevelopmental disorders are non-communicable diseases (NCDs) that not only impact on the quality of life and but also result in substantial economic burden. Immune dysregulation and inflammation are typical hallmarks in both allergic and neurodevelopmental disorders, suggesting converging pathophysiology. Epidemiological studies provided convincing evidence for the link between allergy and neurodevelopmental diseases such as attention-deficit hyperactivity disorder (ADHD) and autism spectrum disorder (ASD). Possible factors influencing the development of these disorders include maternal depression and anxiety, gestational diabetes mellitus, maternal allergic status, diet, exposure to environmental pollutants, microbiome dysbiosis, and sleep disturbances that occur early in life. Moreover, apart from inflammation, epigenetics, gene expression, and mitochondrial dysfunction have emerged as possible underlying mechanisms in the pathogenesis of these conditions. The exploration and understanding of these shared factors and possible mechanisms may enable us to elucidate the link in the comorbidity.

Keywords: allergic disease, neurodevelopmental disorder, mechanisms, attention deficit and hyperactivity disorder, autism spectral disorder

\section{INTRODUCTION}

Both allergic diseases and neurodevelopmental disorders are non-communicable diseases (NCDs) that pose a serious economic burden and impact quality of life (1-4). Allergic diseases typically start early in childhood, with atopic dermatitis (AD) being one of the earliest to manifest in the first few years of life, followed by allergic rhinitis (AR) and asthma (5). Neurodevelopmental disorders have a more variable age of onset but are usually diagnosed before the age of 7 for attention-deficit hyperactivity disorder (ADHD) (6) and diagnosed between the ages of 3 and 5 for autism spectrum disorder $(\mathrm{ASD})(7,8)$. There are postulated links between allergy and neurodevelopmental diseases 
(9-11). Lin et al. found that patients with ADHD and ASD had greater risks of having comorbid allergic diseases including $\mathrm{AD}$, asthma, and AR (11).

Immune dysregulation and inflammation have been well-documented as typical hallmarks in both allergic and neurodevelopmental conditions. Activation of basophils, mast cells, and eosinophils in allergic diseases release proinflammatory factors and cytokines (12). Elevated levels of inflammatory cytokines were similarly found to be associated with the development of $\operatorname{ADHD}$ and $\operatorname{ASD}(13,14)$, together with upregulation of Th2 and Th17 cells in ASD $(15,16)$, suggesting close relations in the pathophysiology of allergy and neurodevelopmental diseases. Recent literature on the role of the immune system in various mental functions also suggests the permeation of peripheral immune cells such as macrophages across the blood-brain barrier, which alter neural functions, potentially playing a role in the development of psychiatric disorders (17). In this review, we present epidemiological evidence linking allergic diseases and neurodevelopmental disorders such as ADHD and ASD, evaluate the shared factors of allergic diseases and altered neurodevelopment, and discuss potential mechanisms underlying the comorbidity. We performed a literature search on PubMed database and identified original research, review, and meta-analysis articles that are relevant to the research topic. Figure 1 shows the literature search strategy for articles that are included in this review.

\section{EPIDEMIOLOGICAL LINK BETWEEN ALLERGY AND ATTENTION-DEFICIT HYPERACTIVITY DISORDER}

ADHD is one of the most common childhood neurodevelopmental disorders (18). According to Diagnostic and Statistical Manual of Mental Disorders (Fifth Edition) (DSM-5) criteria, a child is diagnosed with ADHD if he presents six or more symptoms of inattention, hyperactivity and impulsivity, or both for a period of at least 6 months that has affected daily activities and functioning appropriate for age (19).

A systematic review and meta-analysis provided strong evidence for the link between allergy and ADHD; patients with allergy have a $30-50 \%$ greater risk of developing ADHD (20). Evidence for the association between allergic diseases and ADHD in children is also presented in a number of longitudinal studies. A study by Genuneit et al. comprising a birth cohort of 770 children in Germany reported a significant association between early $\mathrm{AD}$ in the first 4 years of life and ADHD development by 8 years of age (21). In the Twin study of CHild and Adolescent Development (TCHAD), children who had asthma at 8-9 years old had nearly double the risk of having hyperactivity and impulsivity symptoms at 13-14 years old than those without

Abbreviations: $\mathrm{AD}$, atopic dermatitis; $\mathrm{AR}$, allergic rhinitis; $\mathrm{ASD}$, autism spectrum disorder; ATP, adenosine triphosphate; ADHD, attention-deficit hyperactivity disorder; DSM, Diagnostic and Statistical Manual of Mental Disorders; ETC, electron transport chain; GDM, gestational diabetes mellitus; NCD, noncommunicable disease; OVA, ovalbumin; PM, particulate matter; PBMC, peripheral blood mononuclear cells; ROS, reactive oxygen species. asthma, even after adjusting for previous ADHD symptoms (22). Additionally, when analyzing data from each pair of twins, the authors found that $68 \%$ of the phenotypic associations between asthma and hyperactivity-impulsivity symptoms originated from genetic sources, underscoring the potential role of genetics in linking allergy and neurodevelopmental disorders (22). In another longitudinal study in Taiwan comprising 18,473 toddlers aged 1 month up to 3 years with $\mathrm{AD}$, the authors found a significant relationship between $\mathrm{AD}$ and $\mathrm{ADHD}$ as compared with healthy controls without AD (23). Concomitant AR, asthma, and allergic conjunctivitis further increased the odds ratio of developing ADHD than in those with only AD (23).

Besides cohort studies, cross-sectional studies also present data in support of the association between allergy and ADHD. Strom et al. analyzed 19 population-wide surveys in the United States and reported that both $\mathrm{AD}$ and asthma were significantly correlated with increased risks for $\mathrm{ADHD}$ in childhood (24). In a cross-sectional study of 2,772 children aged 3-6 years in Taiwan, Yang et al. reported a significant relationship between $\mathrm{AD}$ with allergen sensitization and ADHD (OR: 4.50, 95\% CI: 1.28-15.86), as well as between asthma with allergen sensitization and ADHD (OR: 3.65, 95\% CI: 1.0712.49) (25). Similarly, a large population-based case-control study conducted in Taiwan showed that children with AD and asthma had a 1.48 times increased risk of developing ADHD (26). The relative risk of asthma and AR was 1.60 and 1.38 times higher, respectively, in a cohort of 549 Korean children with ADHD than in controls without ADHD (27). Jiang et al. conducted a cross-sectional study in China comprising schoolage children from 5 to 12 years old and found food allergy to be significantly associated with ADHD (28). In addition, the risk of ADHD was elevated with increased number of allergic conditions (28). Taken together, current evidence in the field suggests that there is a strong association between allergy and ADHD and that children with allergy may be at increased risk of developing ADHD. Table 1 presents the results from studies on allergy and ADHD.

\section{EPIDEMIOLOGICAL LINK BETWEEN ALLERGY AND AUTISM SPECTRUM DISORDER}

ASD, commonly known by the term autism, is a condition that causes impairment in a wide range of cognitive-emotional and social functions of affected individuals (29). Diagnosis is commonly conducted with the use of the DSM-5 (19), which names the following as common symptoms for diagnosis: (1) persistent impaired social skills, (2) limited and repetitive behavior with the need to follow rigid routines, and (3) heightened or dull reactions to sensory stimuli. Apart from developmental and behavioral problems (30), individuals with ASD have been commonly found to suffer from other comorbidities such as allergic diseases.

Evidence from a number of longitudinal studies showed that subjects who developed allergic conditions such as $\mathrm{AD}$ and asthma in early life had an increased risk of being diagnosed with 


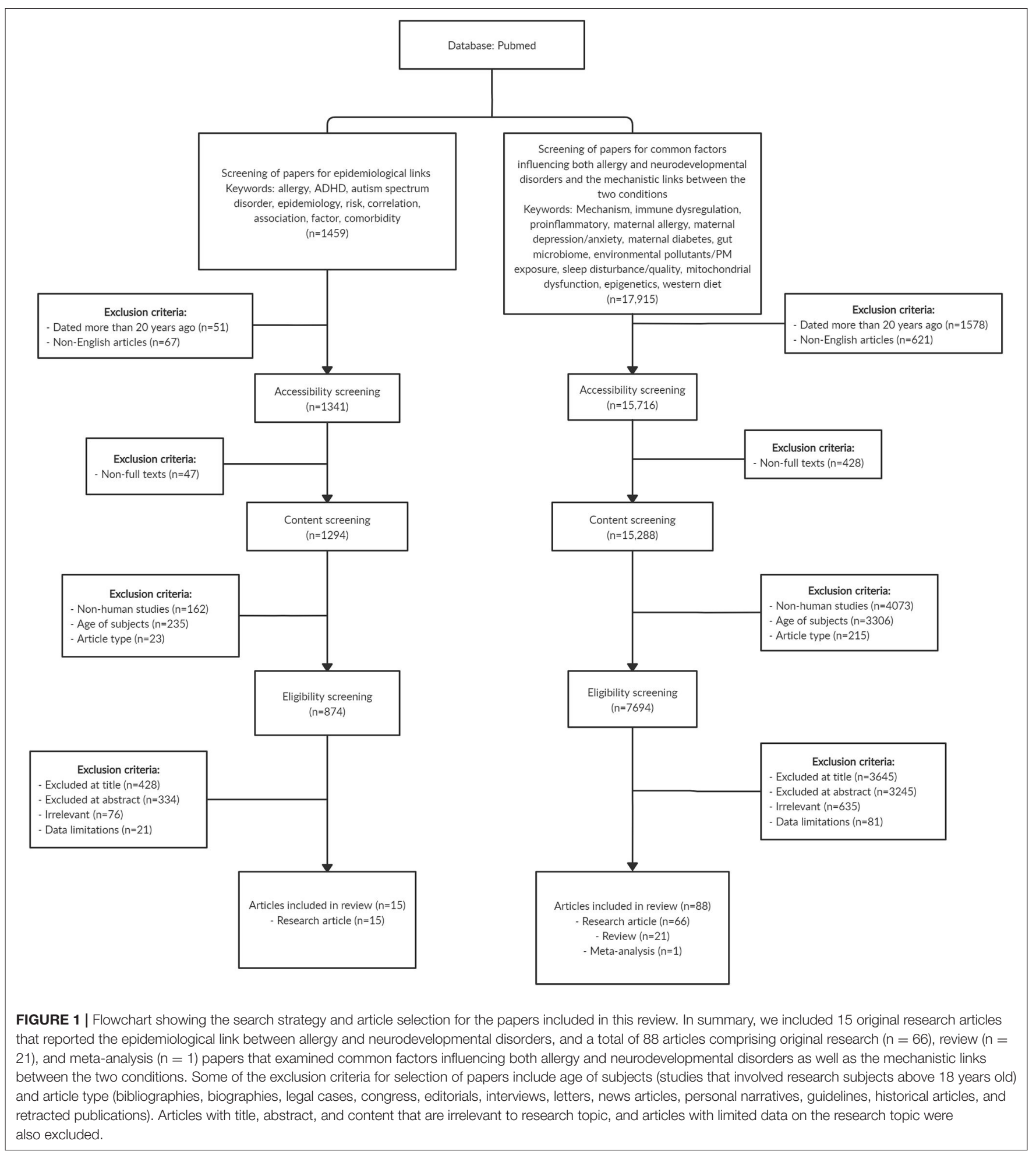

ASD subsequently. A Taiwanese study found that children who developed allergic conditions before the age of 3 had increased risk of being diagnosed with ADHD and ASD; and interestingly, this risk increased with the number of allergic comorbidities (31).
Another study conducted in Taiwan also reported a correlation between $\mathrm{AD}$ diagnosis before age 2 and increased risk of ADHD and ASD. This risk increased even further in children with severe AD and with concomitant atopic respiratory diseases (32). 
TABLE 1 | Summary of epidemiological link between allergy and ADHD.

\begin{tabular}{|c|c|c|c|c|c|c|}
\hline Title of article & Country & Study design & Sample size & $\begin{array}{l}\text { Age range in } \\
\text { years }\end{array}$ & $\begin{array}{l}\text { Allergic } \\
\text { conditions }\end{array}$ & Outcome \\
\hline $\begin{array}{l}\text { Infant atopic eczema and } \\
\text { subsequent attention-deficit } \\
\text { hyperactivity disorder - A } \\
\text { prospective birth cohort study } \\
\text { (21) }\end{array}$ & Germany & $\begin{array}{l}\text { Prospective birth } \\
\text { cohort study }\end{array}$ & 770 & Birth to 11 & $\begin{array}{l}\text { - Atopic } \\
\text { eczema (AE) }\end{array}$ & $\begin{array}{l}\text { - Parental reported AE in early life up to } 4 \text { years was significantly } \\
\text { associated with both early and late ADHD (RR: } 1.92,95 \% \\
\text { Cl: } 1.03-3.57 \text { ) } \\
\text { - Doctor diagnosed AE in first } 4 \text { years of life was significantly } \\
\text { associated with early development of ADHD in first } 8 \text { years of } \\
\text { life (RR: } 2.58,95 \% \mathrm{Cl} \text { : 1.11-5.99) }\end{array}$ \\
\hline $\begin{array}{l}\text { Association between } \\
\text { childhood asthma and ADHD } \\
\text { symptoms in adolescence-A } \\
\text { prospective population-based } \\
\text { twin study (22) }\end{array}$ & Sweden & $\begin{array}{l}\text { Prospective } \\
\text { population-based } \\
\text { twin study }\end{array}$ & 1,812 & $\begin{array}{l}\text { First timepoint: } \\
8-9 \\
\text { Second } \\
\text { timepoint: } \\
\text { 13-14 }\end{array}$ & - Asthma & $\begin{array}{l}\text { - Asthma at } 8-9 \text { years was significantly linked with elevated risks } \\
\text { of } 4 \text { (OR: } 2.77,95 \% \mathrm{Cl}: 1.23-6.26), 5 \text { (OR: } 3.62,95 \% \mathrm{Cl} \text { : } \\
\text { 1.04-12.57), or } 6 \text { (OR: } 8.36,95 \% \mathrm{Cl}: 1.52-45.81) \text { symptoms of } \\
\text { inattention at } 13-14 \text { years } \\
\text { - Children with asthma at 8-9 years exhibited more than double } \\
\text { the odds of having } 3 \text { hyperactivity-impulsivity symptoms at } \\
\text { 13-14 years (OR: } 2.50,95 \% \mathrm{Cl}: 1.46-4.28 \text { ) }\end{array}$ \\
\hline $\begin{array}{l}\text { Longitudinal association } \\
\text { between early atopic } \\
\text { dermatitis and subsequent } \\
\text { attention-deficit or autistic } \\
\text { disorder (23) }\end{array}$ & Taiwan & $\begin{array}{l}\text { Population-based } \\
\text { case-control study }\end{array}$ & $\begin{array}{l}18,473 \mathrm{AD}, \\
18,473 \\
\text { controls }\end{array}$ & $\begin{array}{l}1 \text { month-3 } \\
\text { years }\end{array}$ & $\begin{array}{l}\text { - AD } \\
\text { - Asthma } \\
\text { - AR } \\
\text { Allergic conjunctivitis }\end{array}$ & $\begin{array}{l}\text { - Children with AD had significantly earlier age of diagnosis for } \\
\text { ADHD compared with controls }(p<0.001) \\
\text { - AD in children was significantly associated with elevated risks of } \\
\text { tis development of ADHD (HR: 2.92, 95\% Cl: 2.48-3.45) and ASD } \\
\text { (HR: 8.90, 95\% Cl: 4.98-15.92) } \\
\text { - Comorbid asthma, AR, and allergic conjunctivitis further } \\
\text { increased the risk of ADHD (HR: 4.67, 95\% Cl: 3.81-5.43) and } \\
\text { ASD (HR: } 16.25,95 \% \mathrm{Cl}: 8.63-30.60)\end{array}$ \\
\hline $\begin{array}{l}\text { Association between atopic } \\
\text { dermatitis and attention deficit } \\
\text { hyperactivity disorder in U.S. } \\
\text { children and adults (24) }\end{array}$ & United States & $\begin{array}{l}\text { Cross-sectional } \\
\text { population-based } \\
\text { surveys }\end{array}$ & $\begin{array}{l}354,416 \text { children } \\
34,613 \text { adults }\end{array}$ & $\begin{array}{l}\text { Children: 2-17 } \\
\text { Adults: } 18 \text { and } \\
\text { above }\end{array}$ & $\begin{array}{l}\text { - } A D \\
\text { - Asthma } \\
\text { - Hay fever }\end{array}$ & $\begin{array}{l}\text { - } A D \text { in children was significantly linked with elevated risks of } \\
\text { ADHD }(p<0.05) \text { after adjustment for health-care utilization, } \\
\text { sociodemographic data, and comorbid allergic disease } \\
\text { - } A D \text { in adults was significantly linked with elevated risks of } \\
\text { ADHD }(p<0.05) \text { after adjustment for health-care utilization, } \\
\text { sociodemographic data, and comorbid allergic disease } \\
\text { - All severity levels of ADHD including mild, moderate, and severe } \\
\text { were significantly linked with elevated risks of } A D(p<0.05)\end{array}$ \\
\hline $\begin{array}{l}\text { Association between allergic } \\
\text { diseases, allergic sensitization } \\
\text { and } \\
\text { attention-deficit/hyperactivity } \\
\text { disorder in children: A } \\
\text { large-scale, population-based } \\
\text { study (25) }\end{array}$ & Taiwan & $\begin{array}{l}\text { Population-based } \\
\text { cross-sectional } \\
\text { survey }\end{array}$ & 2,772 & $3-6$ & $\begin{array}{l}\text { - AD } \\
\text { - Asthma } \\
\text { - Allergic } \\
\text { rhinitis } \\
\text { - Allergic } \\
\text { conjunctivitis } \\
\text { - Food allergy }\end{array}$ & $\begin{array}{l}\text { - AD comprising allergic sensitization was significantly linked with } \\
\text { ADHD }(p<0.05) \text { after adjustment for age, birth weight, sex, } \\
\text { maternal history of allergy, maternal education, and period of } \\
\text { breastfeeding } \\
\text { - Asthma comprising allergic sensitization was significantly linked } \\
\text { with ADHD }(p<0.05) \text { after adjustment for age, birth weight, } \\
\text { sex, maternal history of allergy, maternal education, and period } \\
\text { of breastfeeding } \\
\text { - Sensitization to mite allergen was significantly associated with } \\
\text { ADHD }(p<0.05)\end{array}$ \\
\hline $\begin{array}{l}\text { Association between atopic } \\
\text { diseases and attention-deficit } \\
\text { hyperactivity disorder in } \\
\text { childhood: A } \\
\text { population-based }\end{array}$ & Taiwan & $\begin{array}{l}\text { Population-based } \\
\text { case-control study }\end{array}$ & $\begin{array}{l}\text { 4,692 ADHD, } \\
18,768 \\
\text { controls }\end{array}$ & Up to 18 & $\begin{array}{l}\text { - } \text { AD } \\
\text { - Asthma } \\
\text { - Allergic } \\
\text { rhinitis } \\
\text { - Allergic conjunctivitis }\end{array}$ & $\begin{array}{l}\text { - } A D, A R \text {, asthma, and allergic conjunctivitis were all significantly } \\
\text { linked with } A D H D \text { independently }(p<0.001) \\
\text { - Increasing number of allergic diseases was significantly } \\
\text { associated with increasing risk of ADHD after adjustment for } \\
\text { tis age, sex, and urbanization }(p<0.001)\end{array}$ \\
\hline
\end{tabular}


Additionally, children who developed asthma before the age of 3 also had a higher cumulative incidence and risk of being diagnosed with ASD at the 8-year follow-up (33).

Supporting evidence was also provided by cross-sectional studies. A recent study by $\mathrm{Xu}$ et al. observed significant positive relationships between ASD and skin, respiratory, and food allergy among children in the United States, with food allergy showing the strongest association (34). In another study conducted in the United States, children with lower Ages \& Stages Questionnaire (ASQ) communication scores at age 3 had up to three times increased risk of being diagnosed with food allergy, while children with $\mathrm{AD}$ at age 3 had approximately double the risk of having a low ASQ communication score (35). The positive relationship between food allergy and ASD is further supported by results from the CHildhood Autism Risk from Genetics and the Environment (CHARGE) study, which compared the allergy profile of 560 children with ASD and 391 non-ASD children and noted a higher prevalence of food allergy in the group of children with ASD (36). While most studies point to the positive association between allergy and ASD, a study conducted on 30 children with ASD in Turkey found no associations between ASD and allergic symptoms (37). This could be due to the small sample size involved, limiting statistical power. However, a larger cross-sectional study in the United States comprising 77,951 children provided evidence for a positive correlation between ASD and allergy, where the prevalence of asthma was $35 \%$ higher in children with ASD (38). Table 2 presents the results of studies on allergic diseases and ASD.

\section{COMMON FACTORS IMPLICATED IN BOTH ALLERGIC DISEASES AND NEURODEVELOPMENTAL DISORDERS}

Evidence from a number of studies had highlighted common factors such as maternal depression, anxiety, gestational diabetes, maternal allergic status, environmental factors, microbiome dysbiosis, and sleep disturbances in both neurodevelopmental and allergic diseases. In this next section, we present evidence on the involvement of these factors in neurodevelopmental and allergic diseases.

\section{Maternal Depression and Anxiety}

The link between allergy and neurodevelopmental disorders may be established before birth, during the critical preconception and prenatal period. There is increasing evidence to show that stress, depression, or anxiety in the mother before or during pregnancy and after birth can have far-reaching effects on the infant, rendering them more susceptible to development of allergic diseases $(39,40)$ and/or neurodevelopmental disorders $(41,42)$. Maternal depression leads to changes in glucocorticoid sensitivity and an imbalance in pro-inflammatory cytokines levels $(43,44)$, potentially altering the immunological profile of the offspring. In addition, the decrease in placental monoamine oxidase $\mathrm{A}$ in depression causes elevated levels of serotonin (45) that may negatively impact fetal brain development (46). 
TABLE 2 | Summary of epidemiological link between allergy and ASD.

\begin{tabular}{llllll}
\hline Title of article & Country & Study design & Sample size & $\begin{array}{l}\text { Age range in } \\
\text { years }\end{array}$ & $\begin{array}{l}\text { Allergic } \\
\text { conditions }\end{array}$ \\
\hline Is atopy in early childhood a & Taiwan & Longitudinal & 14,812 atopic, & $10-13$ at end & O Asthma
\end{tabular}

risk factor for ADHD and

ASD? A longitudinal study (31)
6,944

non-atopic
- AR

- Allergic

conjunctivitis

- $A D$
387,262 with

nitudinal con

study

spectrum disorder and

attention deficit/hyperactivity

disorder (32)

\section{Increased risk of autism}

spectrum disorder among

early life asthma patients: an

8-year nationwide

population-based prospective

study (33)
Taiwan

Population-based
prospective study

2,134

asthmatic

infants and

children, 8,563

controls
Association of food allergy

and other allergic conditions

with autism spectrum disorder

in children (34)
United States

Cross-sectiona

population-based

surveys
199,520
children

$3-17$

$\begin{array}{ll}6-10 \text { at end of } & -A D \\ \text { follow-up } & \text { AR } \\ & \text { A Asthma }\end{array}$

8-11 at end of

follow-up

$\left(\frac{10}{2}\right.$
- Asthma

- Asthma

developed ASD in later life ( 0.8 vs. $0.2 \%, p<0.001)$ compared with children without atopic disorders

- Higher proportion of children with atopic disorders in early life developed ADHD (6.3 vs. $2.9 \%, p<0.001$ ) in later life compared with children without atopic disorders

- Increase in atopic comorbidities increased the risk of ASD development in children (HR: 4.29, 95\% Cl: 2.25-8.19 for children with four atopic conditions compared with HR: 2.14, 95\% Cl: 0.90-5.11 for children with only 1 atopic condition)

- AD diagnosis before 2 years of age was associated with higher risk of ASD (HR: 1.10; 95\% Cl: 1.03-1.18) and ADHD (HR: 1.16; 5\% Cl: 1.13-1.19) development

- Early onset of respiratory diseases before 2 years of age was associated with higher risk of ASD (HR: $1.49 ; 95 \% \mathrm{Cl}$ : 1.35-1.64) and ADHD (HR: 1.68; 95\% Cl:

1.62-1.75) development

- Higher proportion of children with asthma in early life developed ASD in later childhood ( $1.3 \%$ vs. $0.7 \%, p=0.007$ ) compared with children without asthma.

- After adjustment for age, gender, urbanization level, and allergy comorbidities, infants and children with asthma had an increased risk of ASD development in later life (HR: 2.01, 95\% Cl: 1.193.40)

- Asthmatic subjects who later developed ASD entered asthma remission at an older age as compared with non-ASD asthmatic subjects ( $5.41 \pm 3.09$ vs. $4.30 \pm 3.04$ years, $p=0.059$ )

- Asthmatic subjects who later developed ASD experienced an increased duration of asthma (3.83 \pm 3.25 vs. $2.97 \pm 2.94$ years, $p=0.132$ ) as compared with those without ASD

- Increase in weighted prevalence of reported food, respiratory, and skin allergies in children with ASD $(11.25,18.73$, and $16.81 \%$, respectively), as compared with children without ASD (4.25, 12.08, and $9.84 \%$, respectively)

- Respiratory

allergy

- AD or other skin allergy

- Significantly positive association between food allergy (OR: 2.29; 95\% Cl: 1.87-2.81), respiratory allergy (OR: 1.28; 95\% Cl: 1.101.50 ), and skin allergy (OR: 1.50 ; $95 \% \mathrm{Cl}$ : 1.28-1.77) and ASD after adjusting for sociodemographic data and other allergies

- OR of ASD was 1.82, 95\% Cl: 1.62-2.04 ( $p<0.001)$ in children with allergy as compared with those without 
TABLE 2 | Continued

\begin{tabular}{|c|c|c|c|c|c|c|}
\hline Title of article & Country & Study design & Sample size & $\begin{array}{l}\text { Age range in } \\
\text { years }\end{array}$ & $\begin{array}{l}\text { Allergic } \\
\text { conditions }\end{array}$ & Outcome \\
\hline $\begin{array}{l}\text { Allergic disease and low ASQ } \\
\text { communication score in } \\
\text { children (35) }\end{array}$ & United States & $\begin{array}{l}\text { Cross-sectional } \\
\text { population-based } \\
\text { surveys }\end{array}$ & 715 children & $\begin{array}{l}\text { Birth to } 8.5 \\
\text { ASQ score } \\
\text { taken at age 3; } \\
\text { food allergy } \\
\text { reported at } \\
\text { ages } 3 \text { and } 6\end{array}$ & $\begin{array}{l}\text { - AD } \\
\text { - Food allergy } \\
\text { - Asthma }\end{array}$ & $\begin{array}{l}\text { - Higher proportion of children with lower ASQ score were } \\
\text { diagnosed with ASD by age } 8 \text { compared with those with normal } \\
\text { scores ( } 11.1 \text { vs. } 1.2 \% ; p<0.001) \text {, } \\
\text { - Higher proportions of children with lower ASQ score reported } \\
\text { having food allergy at age } 6 \text { ( } 17.6 \% \text { for low ASQ score group } \\
\text { vs. } 4.7 \% \text { for normal development group; } p=0.007) \\
\text { - Children with food allergy at ages } 3 \text { or } 6 \text { were approximately three } \\
\text { times more likely to have lower ASQ scores }(p=0.030) \\
\text { - Children with AD diagnosis at age } 3 \text { were twice as likely to have } \\
\text { a low ASQ score }(p=0.054) \text { as compared with those } \\
\text { without AD }\end{array}$ \\
\hline $\begin{array}{l}\text { Asthma and allergies in } \\
\text { children with autism spectrum } \\
\text { disorders: results from the } \\
\text { CHARGE Study (36) }\end{array}$ & United States & $\begin{array}{l}\text { Population-based } \\
\text { case-control study }\end{array}$ & $\begin{array}{l}560 \text { ASD, } 391 \\
\text { controls }\end{array}$ & $\begin{array}{l}2-5 \text { at study } \\
\text { enrolment }\end{array}$ & $\begin{array}{l}\text { - Asthma } \\
\text { - Food allergy }\end{array}$ & $\begin{array}{l}\text { - Risk of asthma did not differ in ASD and non-ASD subjects (16\%, } \\
p=0.93 \text { ) } \\
\text { - Children with ASD were two times as likely to report having food } \\
\text { allergies (Adj OR: } 2.23,95 \% \mathrm{Cl}: 1.28-3.89 \text { ) }\end{array}$ \\
\hline $\begin{array}{l}\text { Co-occurrence of autism and } \\
\text { asthma in a nationally } \\
\text { representative sample of } \\
\text { children in the United States } \\
\text { (38) }\end{array}$ & United States & $\begin{array}{l}\text { Cross-sectional } \\
\text { population-based } \\
\text { surveys }\end{array}$ & $\begin{array}{l}77,951 \\
\text { children }\end{array}$ & $3-18$ & - Asthma & $\begin{array}{l}\text { - Risk of asthma is higher in children with ASD after adjustment } \\
\text { for sociodemographic factors, body mass index, prior brain } \\
\text { injury, and exposure to passive smoke (Adj OR: 1.19, 95\% } \\
\text { Cl: 1.03-1.36) }\end{array}$ \\
\hline
\end{tabular}


In the Born in Guangzhou Cohort Study (BIGCS), Wei et al. studied 8,580 mother-infant pairs to investigate the link between maternal depressive symptoms during pregnancy and subsequent $\mathrm{AD}$ development in the infant at 12 months (47). They found maternal depressive symptom scores to be positively associated with the risk of $\mathrm{AD}$ in the infant during the 1st year of life (47). Similarly, in another study of two birth cohorts including the Cohort for Childhood Origin of Asthma and Allergic Diseases (COCOA) cohort and the Panel Study on Korean Children (PSKC) cohort, prenatal maternal anxiety and depression were found to be significantly associated with elevated risks of $\mathrm{AD}$ in the infant in both cohorts (48).

Analogous associations have been reported in studies involving ADHD subjects. Van der Bergh and Marcoen found prenatal maternal anxiety to be significantly associated with ADHD traits at 8 and 9 years old (49). Elevated serum IgE levels were also reported in children of mothers who experienced prenatal distress, another indicator of Th2-biased immune responses (48). Maternal levels of pro-inflammatory IL-6 and Creactive protein levels in the third trimester were associated with offspring cognitive functioning and behavior (50).

\section{Gestational Diabetes Mellitus}

Gestational diabetes mellitus (GDM) has been reported to be a risk factor for both allergic diseases and ASD. A positive association was found between GDM and development of asthma and wheezing in the offspring $(51,52)$. The risk of early childhood AD was reportedly increased by 7.5 times and allergen sensitization by six times in infants born to mothers with GDM (53). Similarly, a meta-analysis also revealed the risk of ASD in offspring to be twice as high in mothers with GDM (54). Furthermore, in a cohort of 419,425 children in the United States, the risk of ASD development in the offspring was increased when the mother had type 1 diabetes, type 2 diabetes, and GDM (55). This may be due to the induction of a pro-inflammatory state through the increase in levels of cytokines including TNF- $\alpha$ and IL-6 (56) and the decrease in anti-inflammatory factors such as IL-10 in GDM (57). This inflammatory profile was also observed in ADHD patients where serum IL-6 levels were significantly higher than in healthy controls (58), while TNF- $\alpha$ levels had been reported to be elevated in children with ASD (59). Besides this, the severity of ASD (60) and AD (61) had been reported to increase with the levels of pro-inflammatory cytokines.

\section{Maternal Allergic Status}

The influence of maternal allergy on the development of allergic diseases in the offspring is well-documented. An analysis in the PRogramming of Intergenerational Stress Mechanisms (PRISM) cohort comprising 553 mother-child pairs showed that offspring born to mothers with allergic history had elevated risks of developing asthma (62). Another study also reported higher risk of $\mathrm{AD}$ and $\mathrm{AR}$ development in offspring born to mothers with history of asthma and AR during pregnancy, respectively (63). Maternal history of asthma was significantly correlated with greater risks of wheezing in the child (64). Likewise, maternal asthma has been reported to increase the risk of ADHD (65) development, while maternal asthma and allergy were found to increase the risk for ASD in offspring (66). Possible mechanisms suggested for these associations include epigenetic influences (67), exposure to common environmental conditions (68), and alterations to immunological profiles (66). Interestingly, it is noteworthy that the effects of maternal allergy on offspring outcomes may follow sex-specific patterns. Clifton et al. highlighted that female infants of asthmatic mothers who did not use steroid inhalers had significantly lower birth weights, but male infants were not affected (69). The sex-specific effect of maternal allergy on birth outcomes was also observed in the association between maternal atopic status and risk of ADHD in offspring. Cowell et al. analyzed a cohort comprising 250 mother and child pairs and found that maternal atopic status was associated with greater risk of ADHD behavior in the child, and this association was more prominent for female infants (70).

\section{Environmental Factors \\ Diet}

Environmental factors such as diet may play a role in influencing the development of both allergy and neurodevelopmental disorders. In a review by Skypala et al. the authors presented compelling evidence on how a western diet is composed of refined grains, high fat, and sugar was significantly correlated with wheezing in children, and countries with westernized lifestyles were especially at risk of higher food allergy rates (71). Julia et al. highlighted the increase in prevalence of allergic diseases with westernized lifestyles and diet, and they proposed mechanisms by which saturated fatty acids lead to allergic inflammation and how a lack of fiber and several vitamins in western diets result in the loss of protective effects against systemic inflammation (72). Similarly, ADHD patients were observed to have increased intake of refined grains and lower intake of vitamin B2 and dairy than have controls (73). In the Raine study, a western diet high in refined sugars and fat has been found to be linked with ADHD (74). Adverse impact of western diet on hippocampal functioning and neuroinflammation has been reported in a review by Noble et al. (75). Moreover, dietary differences may contribute to gut microbiome dysbiosis observed in patients with allergy and neurodevelopmental disorders $(75,76)$.

\section{Exposure to Environmental Pollutants}

Early life exposure to particulate matter (PM) or other pollutants may influence the development of both allergy and neurodevelopmental disorders. There is strong evidence to support the link between environmental PM and allergic disorders, as demonstrated in various studies (77-80). A review by $\mathrm{Wu}$ et al. highlighted the detrimental impact of PM exposure on asthma and AR and discussed the possible mechanisms by which different PM subtypes could elicit downstream inflammation and oxidative stress (77). Another prospective birth cohort study of 2,860 children in Munich also found a significant relationship between $\mathrm{PM}_{2.5}$ exposure and asthma as well as between $\mathrm{NO}_{2}$ exposure and eczema (78). Exposure to toxic metals has been associated with the development of allergic disease. In a study by Kim et al. involving 4,350 children aged 7-8 years, the authors found mercury exposure to be correlated 
with risk of asthma (81). Mercury levels in the blood were also found to be positively correlated with wheezing outcomes and airway hyperresponsiveness (81). In the Mothers and Children's Environmental Health (MOCEH) study comprising a cohort of 1,061 mother-infant pairs, the authors highlighted mercury exposure at 2 years to be a risk factor for $\mathrm{AD}$ development in later childhood (82).

The link between PM exposure and ADHD was similarly discussed in a review by Myhre et al. (83). Prenatal and postnatal exposure to PM was found to be correlated with increased risk of displaying behavioral problems and ADHD symptoms. Additionally, exposure to toxic metals present in PM was also positively associated with ADHD behavior (83). In another study of 116 children aged 8 years or younger diagnosed with ADHD, having living quarters close to streets or motorways resulting in higher exposure to traffic PM was associated with higher risk of developing ADHD (84). Other forms of environmental pollutants including toxic metals such as mercury and lead had also been postulated as potential risk factors for ASD (85). Likewise, a study of 284 children with ASD found a possible link between high concentration of toxic metals in ambient air with ASD (86).

\section{Microbiome Dysbiosis}

The microbiome is another key player in the link between allergy and neurodevelopmental disorders. It is well-established that gut microbiome dysbiosis plays an important role in allergic diseases such as AD (87), and similar shifts in host microbiome are increasingly being elucidated in ADHD patients (88). Additionally, the role of microbiome in influencing allergy and neurodevelopmental disorders may stem from maternal factors such as stress during the prenatal period, as well as differing dietary patterns. Zijlmans et al. studied a cohort of 56 infants and found that maternal stress was linked with dysregulation of the infant intestinal microbiome, characterized by elevated levels of pathogenic species such as Enterobacter and decreased levels of commensal Bifidobacteria and Lactobacillus, contributing to an overall increase in inflammatory state (89). These same bacterial species have also been implicated in neurodevelopmental disorders. A review conducted by Bundgaard-Nielsen et al. (90) on the gut microbiota profiles of ADHD and ASD patients presented convincing evidence on altered gut bacterial composition in ASD individuals as compared with healthy controls, which included increase in Bacteroides and Clostridium as well as the decrease in Bifidobacterium, Streptococcus, and Prevotella in stool microbiota. On the other hand, abundance of Parabacteroides, Prevotella, and Lactobacillus were decreased in ADHD patients. A prospective study on 93 children from infancy to 8 years of age reported decreased Bacteroides, Prevotella, and Coprococcus in stool samples of children with allergy as compared with healthy children across various time points, while Lactobacillus, Enterococcus, and Lachnospira were found to be decreased and Bifidobacterium increased in children with allergy at 8 years of age (91). Another study on 89 children from the United States found that gut microbiome at age 1 affects cognitive function at age 2 . Children with abundance of
Bacteroides and Faecalibacterium were found to exhibit the best and worst cognitive capabilities, respectively (92).

Szopinska-Tokov et al. found that ADHD patients had lower beta diversity in their gut microbiome than controls (93). Additionally, a specific genus, Ruminococcaceae_UCG_004, was linked to symptoms of inattention (93). In another review by Cenit et al. the authors discuss how specific bacteria in the gut have the capability to produce and influence important neurotransmitters including gamma-aminobutyric acid (GABA) and serotonin (88). Downregulation of Bifidobacterium and Lactobacillus, which produce GABA, as well as Streptococcus spp. and Enterococcus spp., which produce serotonin in the stool microbiota of ASD and ADHD patients have been observed (90). Serotonin and GABA produced by gut bacteria can potentially interact with epithelial cells to stimulate the release of other cytokines and hormones, which in turn regulate neuronal signaling to influence brain functioning (88). Higher abundance of Neisseriaceae and Bacteroidaceae and a significant reduction in gut microbiome diversity was also observed in the ADHD group as compared with controls (94). Similar to these findings, increased abundance of Bacteroidaceae in the gut has previously been found to be associated with $\mathrm{AD}$ groups compared with controls $(95,96)$.

\section{Sleep Disturbances}

Many studies have reported that $\mathrm{AD}$ disrupts sleep quality, especially so when $\mathrm{AD}$ is coupled with other comorbidities such as AR and asthma (97-100). Disease severity of AD was found to be inversely correlated with sleep quality, with scratching being one of the main reasons for poor sleep (98). A study in Korea reported increased sleep problems among children with AR and $\mathrm{AD}$. The severity of the sleep problems was positively correlated to the percentage of eosinophils measured in the peripheral blood (101). Inadequate sleep, when coupled with $\mathrm{AD}$, resulted in a 2 -fold increase in the risk of ADHD compared with that in subjects with $\mathrm{AD}$ and adequate sleep (24). These findings were replicated in another study of 6,484 children based in Germany, whereby the risk of ADHD was significantly higher in children with both atopic $\mathrm{AD}$ and sleep disturbances (102). Disturbances to sleep can lead to abnormal functioning of various brain circuits, including the prefrontal cortex, which in turn influences behavior and cognitive operations (103). Executive functioning is usually defective in $\mathrm{ADHD}$, and hence, poor sleep quality may collectively enhance the probability of developing symptoms of ADHD in patients with allergic diseases (104). Similarly, a study by Mazurek et al. highlighted a significant link between behavioral problems in ASD children and poor sleep (105). Sleep disturbances are known to aggravate various behavioral problems in ASD patients and disrupt daytime functioning (106).

\section{POSSIBLE MECHANISMS LINKING ALLERGY AND NEURODEVELOPMENTAL DISORDERS}

Apart from inflammation, which is the common underlying mechanism for allergy and neurodevelopmental disorders, 
epigenetics and gene expression and mitochondrial dysfunction have emerged as possible mechanisms linking the two conditions.

\section{Epigenetics and Gene Expression}

Environmental exposure in early life is linked to the development of allergic and neurodevelopmental diseases $(107,108)$, and epigenetic mechanisms, which conveyed genomic adaptation to environmental factors, may explain the effects of the environment on the development of allergic and neurodevelopmental conditions $(109,110)$.

$\mathrm{Xu}$ et al. conducted a large-scale epigenome-wide association study in the whole blood of 392 children with asthma and 1,156 controls aged 4-8 years, and they found 14 differentially methylated $\mathrm{CpG}$ sites that were subsequently validated through meta-analysis of six independent European cohorts (111). The methylated CpG sites were associated with whole blood transcriptional profiles related to increased activation of eosinophils, cytotoxic $\mathrm{T}$ cells, and natural killer cells and reduced number of naive $\mathrm{T}$ cells (111). Similarly, another epigenome-wide meta-analysis study also reported CpG methylation and differentially methylated regions in children with asthma, and pathway analyses showed that the methylated CpG and differentially methylated regions were associated with asthma-related immune processes (112).

van Mil et al. assessed the DNA methylation profiles of selected genes that are involved in neurotransmitter system and neurodevelopment in the cord blood samples of an ongoing population-based birth cohort (113). The group found that lower methylation levels of seven genes assessed at birth were associated with more ADHD symptoms at 6 years of age (113). More recently, a large epigenome-wide association study of childhood ADHD reported different DNA methylation profiles and differentially methylated sites between ADHD cases and controls (114). The differentially methylated sites were associated with $\mathrm{ADHD}$ risk variants, suggesting that genetic risk factors may influence ADHD through epigenetic mechanism (114).

Taken together, epigenetic and gene expression may be a common underlying mechanism in the etiology of allergy and neurodevelopmental disorders. Interestingly, a study conducted in a mouse model of maternal allergic asthma provides evidence that allergy and neurodevelopmental disorders may be linked by epigenetic mechanisms (115). The offspring from female mice with allergic asthma showed behavioral abnormalities including deficits in social interactions, increased marble burying, and decreased grooming as compared with offspring from female mice without allergic asthma (115). Microglia isolated from the brains of offspring with maternal allergic asthma had differentially methylated regions enriched for immune signaling pathway and important microglial developmental transcription factor-binding motifs. Moreover, both differentially methylated regions and differentially expressed genes found in microglia of offspring with maternal allergic asthma significantly overlapped with genes that are differentially expressed in the human ASD cortex (115). These findings suggest that maternal allergic asthma can cause neurodevelopmental disorder such as ASD in offspring, and epigenetics may be the underlying mechanism linking allergy and ASD.

\section{Mitochondrial Dysfunction}

Mitochondrial dysfunction is characterized by loss of efficiency in electron transport chain (ETC) and reduced production of energy in the form of adenosine triphosphate (ATP), which is essential for cellular metabolism and function. The malfunctioning is driven by oxidative stress and reactive oxygen species (ROS) production, and malfunctioning mitochondria alter the bioenergetics and metabolic profile of the cell to favor systemic inflammation that plays a central role in the pathogenesis of chronic diseases, e.g., allergy and neurodevelopmental disorders $(116,117)$.

Raby et al. reported a significant association between mitochondrial haplotype and total serum IgE levels and that haplogroup $U$ carriers had greater skin prick test reactivity and higher rate of $\mathrm{AD}$ (118). A recent study by Ederle et al. showed that peripheral blood mononuclear cells (PBMCs) of severe asthmatic patients had increased mitochondrial respiratory chain complexes activity and ROS production than had PBMCs of healthy subjects (119). Mitochondrial dysfunction in the form of reduced cytochrome $c$ expression and activity and decreased lung ATP levels was observed in ovalbumin (OVA)-induced experimental allergic asthma mice, and anti-inflammatory IL-4 antibody treatment was able to reverse the mitochondrial dysfunction, indicating a link between mitochondrial dysfunction and inflammation in allergic asthma (120). Moreover, induced mitochondrial dysfunction in airway epithelial cells demonstrated exacerbated antigen-driven allergic airway inflammation, suggesting a role of mitochondrial function in regulating inflammation associated with allergic conditions (121).

In a study involving eight children with ASD and eight controls aged 4-10 years, significantly lower ETC complex activities were observed in the cerebellum, frontal cortex, and temporal cortex of the ASD group (122). The reduction in ETC complex activities was also reported in other studies that examined mitochondrial dysfunction in brain of ASD patients $(123,124)$. Verma et al. generated cybrid cell lines by fusing platelets from ADHD and non-ADHD subjects with neuroblastoma cell line devoid of mitochondrial DNA to investigate mitochondrial pathology in ADHD (125). The group demonstrated significantly lower cellular and mitochondrial respiration, reduced ATPase transcript levels, reduced mitochondrial complex activity, loss of mitochondrial membrane potential, and elevated oxidative stress in ADHD cybrid neurons, suggesting a role of mitochondrial pathology in ADHD (125).

Collectively, mitochondrial dysfunction may bridge the gap for understanding how allergy and neurodevelopmental disorders are related (126).

\section{DISCUSSION}

The epidemiological link between allergy and neurodevelopmental disorders such as ADHD and ASD has been established in multiple cross-sectional and longitudinal studies $(24,25,32,34)$. While the cross-sectional studies showed a strong 
association between allergy and neurodevelopmental disorders $(25,28,35,38)$, the longitudinal data indicated that allergy in early life is a strong risk factor for development of ADHD and ASD in later life $(27,31,32)$. Hence, the identification of this group of at-risk subjects with pre-existing allergy conditions may allow early treatment and intervention for ADHD and ASD.

We also discussed common factors that contribute to the development of both allergy and neurodevelopmental disorders, and they included maternal depression and anxiety (43-46), $\operatorname{GDM}(56,57)$, maternal allergic status $(65,66)$, environmental factors such as diet and exposure to environmental pollutants $(77,83)$, microbiome dysbiosis $(90,96)$, and sleep disturbances $(98,102)$. However, there is a lack of direct evidence showing that these factors can connect both allergy and neurodevelopmental disorders. For instance, the risk of developing ADHD and
ASD at later childhood for children with AD born to mothers of depression has not been investigated. Therefore, more longitudinal studies are needed to study the association between the factors and both conditions in the same cohort and also examine the mediating effect of these factors in the association between allergy and neurodevelopmental disorders.

With emerging evidence on the possible links between allergy and neurodevelopment disorders, it is important to understand the underlying mechanisms so as to identify new treatment and therapeutic targets. To further elucidate the role of epigenetics $(111,114)$ and mitochondrial dysfunction $(119,122)$ in contributing to the link and development of allergy and $\mathrm{ADHD}$ and ASD, more in vivo studies are required to examine the methylation pattern and ETC complex activities in animal models that are reflective of the conditions.

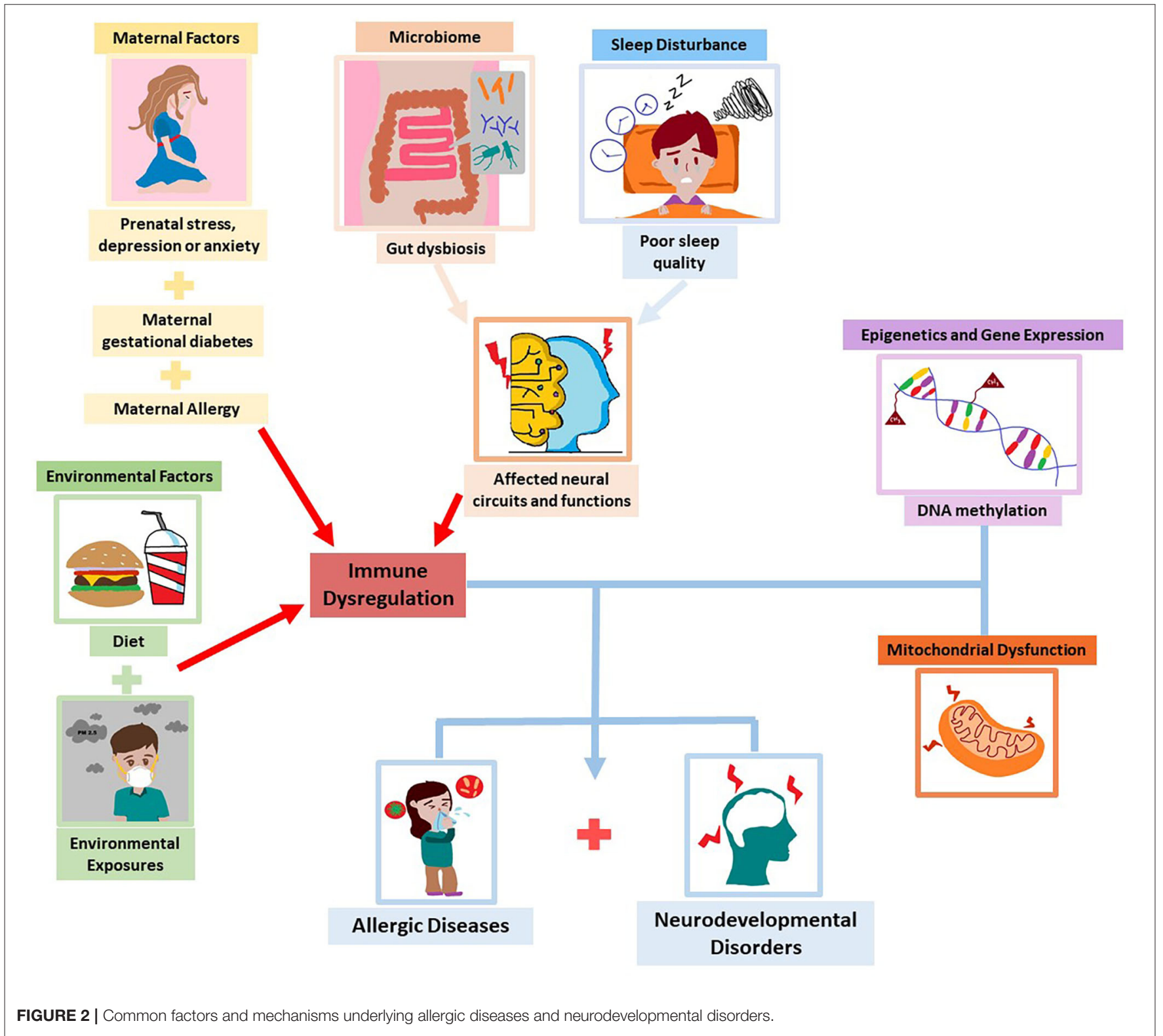




\section{CONCLUSIONS}

In this narrative review, we have discussed the association between allergic diseases and neurodevelopmental disorders such as ADHD and ASD, that both start early in life. Early prevention would be of utmost importance as both disorders pose a serious burden and impact on quality of life. Recent studies reported several factors such as maternal depression and anxiety, GDM, maternal allergic status, diet, exposure to environmental pollutants, microbiome dysbiosis, and sleep disturbances that influence the development of both allergy and neurodevelopmental disorders. Moreover, apart from inflammation, epigenetics and gene expression and

\section{REFERENCES}

1. Anandan C, Gupta R, Simpson CR, Fischbacher C, Sheikh A. Epidemiology and disease burden from allergic disease in Scotland: analyses of national databases. J R Soc Med. (2009) 102:431-42. doi: 10.1258/jrsm.2009. 090027

2. Gupta R, Sheikh A, Strachan DP, Anderson HR. Burden of allergic disease in the UK: secondary analyses of national databases. Clin Experi Allergy. (2004) 34:520-6. doi: 10.1111/j.1365-2222.2004.1935.x

3. Matza LS, Paramore C, Prasad M. A review of the economic burden of ADHD. Cost Effect Res Allocation. (2005) 3:5. doi: 10.1186/1478-7547-3-5

4. Hankin CS. ADHD and its impact on the family. Drug Benefit Trends. (2001) 13:15-6.

5. Bantz SK, Zhu Z, Zheng T. The atopic march: Progression from atopic dermatitis to allergic rhinitis and asthma. J Clin Cell Immunol. (2014) 5:202. doi: 10.4172/2155-9899.1000202

6. Kieling C, Kieling RR, Rohde LA, Frick PJ, Moffitt T, Nigg JT, et al. The age at onset of attention deficit hyperactivity disorder. Am J Psychiatry. (2010) 167:14-6. doi: 10.1176/appi.ajp.2009.09060796

7. Mandell DS, Morales KH, Xie M, Lawer LJ, Stahmer AC, Marcus SC. Age of diagnosis among medicaid-enrolled children with autism, 2001-2004. Psychiatric Ser. (2010) 61:822-9. doi: 10.1176/ps.2010.61.8.822

8. Kurasawa S, Tateyama K, Iwanaga R, Ohtoshi T, Nakatani K, Yokoi K. The age at diagnosis of autism spectrum disorder in children in Japan. Int J Pediatr. (2018) 2018:5374725. doi: 10.1155/2018/5374725

9. Suwan P, Akaramethathip D, Noipayak P. Association between allergic sensitization and attention deficit hyperactivity disorder (ADHD). Asian Pacific J Allergy Immunol. (2011) 29:57-65.

10. Pelsser LM, Buitelaar JK, Savelkoul HF. ADHD as a (non) allergic hypersensitivity disorder: a hypothesis. Pediatric Allergy Immunol. (2009) 20:107-12. doi: 10.1111/j.1399-3038.2008.00749.x

11. Lin TY, Lin PY, Su TP, Chen YS, Hsu JW, Huang KL, et al. Autistic spectrum disorder, attention deficit hyperactivity disorder, and allergy: is there a link? A nationwide study. Res Autism Spectr Disord. (2014) 8:1333-8. doi: 10.1016/j.rasd.2014.07.009

12. Lacy P. Chapter 12 Eosinophil Cytokines in Allergy, in Cytokine Effector Functions in Tissues. Academic Press (2017). p. 173-218. doi: 10.1016/B978-0-12-804214-4.00011-7

13. Theoharides TC, Tsilioni I, Patel AB, Doyle R. Atopic diseases and inflammation of the brain in the pathogenesis of autism spectrum disorders. Transl Psychiatry. (2016) 6:e844. doi: 10.1038/tp.2016.77

14. Donfrancesco R, Nativio P, Benedetto AD, Villa MP, Andriola E, Melegari MG, et al. Anti-yo antibodies in children with adhd: first results about serum cytokines. J Attention Disord. (2016) 24:1497-502. doi: 10.1177/1087054716643387

15. Moaaz M, Youssry S, Elfatatry A, El Rahman MA. Th17/Treg cells imbalance and their related cytokines (IL-17, IL-10 and TGF- $\beta$ ) in children with autism spectrum disorder. J Neuroimmunol. (2019) 337:577071. doi: 10.1016/j.jneuroim.2019.577071 mitochondrial dysfunction have emerged as possible underlying mechanisms in the pathogenesis of these conditions. The exploration and understanding of these shared factors and possible mechanisms may enable us to elucidate the link in the comorbidity (Figure 2).

\section{AUTHOR CONTRIBUTIONS}

RC, MT, and DO performed literature search and wrote the manuscript. KS, ET, LS, and MM critically reviewed and revised the manuscript. EL conceptualized the ideas, critically reviewed, and wrote the manuscript. All authors contributed to the article and approved the submitted version.

16. Molloy CA, Morrow AL, Meinzen-Derr J, Schleifer K, Dienger K, Manning-Courtney $\mathrm{P}$, et al. Elevated cytokine levels in children with autism spectrum disorder. J Neuroimmunol. (2006) 172:198-205. doi: 10.1016/j.jneuroim.2005.11.007

17. Bennett FC, Molofsky AV. The immune system and psychiatric disease: a basic science perspective. Clin Experi Immunol. (2019) 197:294-307. doi: $10.1111 /$ cei. 13334

18. Smidts DJ, Oosterlaan P. How common are symptoms of ADHD in typically developing preschoolers? A study on prevalence rates and prenatal/demographic risk factors Cortex. (2007) 43:710-7. doi: 10.1016/S0010-9452(08)70500-8

19. American Psychiatric Association. Diagnostic and Statistical Manual of Mental Disorders. 5th ed. Washington, DC: American Psychiatric Association (2013).

20. Schans JV, Çiçek R, de Vries TW Hak E, Hoekstra PJ. Association of atopic diseases and attention-deficit/hyperactivity disorder: a systematic review and meta-analyses. Neurosci Biobehav Rev. (2017) 74:139-48. doi: 10.1016/j.neubiorev.2017.01.011

21. Genuneit J, Braig S, Brandt S, Wabitsch M, Florath I, Brenner H, et al. Infant atopic eczema and subsequent attention-deficit/hyperactivity disorder-a prospective birth cohort study. Pediatric Allergy Immunol. (2014) 25:51-6. doi: $10.1111 /$ pai.12152

22. Mogensen $\mathrm{N}$, Larsson $\mathrm{H}$, Lundholm C, Almqvist C. Association between childhood asthma and ADHD symptoms in adolescence - a prospective population-based twin study. Allergy. (2011) 66:1224-30. doi: 10.1111/j.1398-9995.2011.02648.x

23. Lee CY, Chen MH, Jeng MJ, Hsu JW, Tsai SJ, Bai YM, et al. Longitudinal association between early atopic dermatitis and subsequent attention-deficit or autistic disorder: a population-based case-control study. Medicine. (2016) 95:e5005. doi: 10.1097/MD.00000000000 05005

24. Strom MA, Fishbein AB, Paller AS, Silverberg JI. Association between atopic dermatitis and attention deficit hyperactivity disorder in children US, and adults. Br J Dermatol. (2016) 175:920-9. doi: 10.1111/bjd.14697

25. Yang CF, Yang CC, Wang IJ. Association between allergic diseases, allergic sensitization and attention-deficit/hyperactivity disorder in children: a large-scale, population-based study. J Chin Med Assoc. (2018) 81:277-83. doi: 10.1016/j.jcma.2017.07.016

26. Tsai JD, Chang SN, Mou CH, Sung FC, Lue KH. Association between atopic diseases and attention-deficit/hyperactivity disorder in childhood: a population-based case-control study. Ann Epidemiol. (2013) 23:185-8. doi: 10.1016/j.annepidem.2012.12.015

27. Kwon HJ, Lee MY, Ha M, Yoo SJ, Paik KC, Lim J-H, et al. The associations between ADHD and asthma in Korean children. BMC Psychiatry. (2014) 14:70. doi: 10.1186/1471-244X-14-70

28. Jiang X, Shen C, Dai Y, Jiang F, Li S, Shen X, et al. Early food allergy and respiratory allergy symptoms and attention-deficit/hyperactivity disorder in Chinese children: a cross-sectional study. Pediatric Allergy Immunol. (2018) 29:402-9. doi: 10.1111/pai.12888 
29. Miles JH. Autism spectrum disorders-a genetics review. Genetics Med. (2011) 13:278-94. doi: 10.1097/GIM.0b013e3181ff67ba

30. Lai M-C, Lombardo MV, Baron-Cohen S. Autism. Lancet. (2014) 383:896910. doi: 10.1016/S0140-6736(13)61539-1

31. Chen MH, Su TP, Chen YS, Hsu JW, Huang KL, Chang WH, et al. Is atopy in early childhood a risk factor for ADHD and ASD? A longitudinal study. $J$ Psychosom Res. (2014) 77:316-21. doi: 10.1016/j.jpsychores.2014.06.006

32. Liao TC, Lien YT, Wang S, Huang SL, Chen CY. Comorbidity of atopic disorders with autism spectrum disorder and attention deficit/hyperactivity disorder. J Pediatr. (2016) 171:248-55. doi: 10.1016/j.jpeds.2015.12.063

33. Tsai PH, Chen MH, Su TP, Chen YS, Hsu JW, Huang KL, et al. Increased risk of autism spectrum disorder among early life asthma patients: An 8-year nationwide population-based prospective study. Res Autism Spectr Disord. (2014) 8:381-6. doi: 10.1016/j.rasd.2013.12.022

34. Xu G, Snetselaar LG, Jing J, Liu B, Strathearn L, Bao W. Association of food allergy and other allergic conditions with autism spectrum disorder in children. JAMA Network Open. (2018) 1:e180279. doi: 10.1001/jamanetworkopen.2018.0279

35. Yadama AP, Kelly RS, Lee-Sarwar K, Mirzakhani H, Chu SH, Kachroo P, et al. Allergic disease and low ASQ communication score in children. Brain Behav Immun. (2020) 83:293-7. doi: 10.1016/j.bbi.2019.10.008

36. Lyall K, Van de Water J, Ashwood P, Hertz-Picciotto I. Asthma and allergies in children with autism spectrum disorders: Results from the CHARGE study. Autism Res. (2015) 8:567-74. doi: 10.1002/aur.1471

37. Bakkaloglu B, Anlar B, Anlar FY, Oktem F, Pehlivantürk B, Unal F, et al. Atopic features in early childhood autism. Euro J Paediatric Neurol. (2008) 12:476-9. doi: 10.1016/j.ejpn.2007.12.008

38. Kotey S, Ertel K, Whitcomb B. Co-occurrence of autism and asthma in a nationally-representative sample of children in the United States. J Autism Dev Disord. (2014) 44:3083-8. doi: 10.1007/s10803-014-2174-y

39. Chiu YH, Coull BA, Cohen S, Wooley A, Wright RJ. Prenatal and postnatal maternal stress and wheeze in urban children: effect of maternal sensitization. Am J Respir Crit Care Med. (2012) 186:147-54. doi: 10.1164/rccm.201201-0162OC

40. El-Heis S, Crozier SR, Healy E, Robinson SM, Harvey NC, Cooper C, et al. Maternal stress and psychological distress preconception: Association with offspring atopic eczema at age 12 months. Clin Experi Allergy. (2017) 47:760-9. doi: 10.1111/cea.12910

41. Grizenko N, Shayan YR, Polotskaia A, Ter-Stepanian M, Joober R. Relation of maternal stress during pregnancy to symptom severity and response to treatment in children with ADHD. J Psychiatry Neurosci. (2008) 33:10-6.

42. Ronald A, Pennell C, Whitehouse A. Prenatal maternal stress associated with ADHD and autistic traits in early childhood. Front Psychol. (2011) 1:223. doi: 10.3389/fpsyg.2010.00223

43. Shelton MM, Schminkey DL, Groer MW. Relationships among prenatal depression, plasma cortisol inflammatory cytokines. Biol Res Nurs. (2014) 17:295-302. doi: 10.1177/1099800414543821

44. Reynolds RM, Pesonen AK, O’Reilly JR, Tuovinen S, Lahti M, Kajantie E, et al. Maternal depressive symptoms throughout pregnancy are associated with increased placental glucocorticoid sensitivity. Psychol Med. (2015) 45:2023-30. doi: 10.1017/S003329171400316X

45. Blakeley PM, Capron LE, Jensen AB, O’Donnell KJ, Glover V. Maternal prenatal symptoms of depression and down regulation of placental monoamine oxidase A expression. J Psychosom Res. (2013) 75:341-5. doi: 10.1016/j.jpsychores.2013.07.002

46. Bronson SL, Bale TL. The placenta as a mediator of stress effects on neurodevelopmental reprogramming. Neuropsychopharmacology. (2016) 41:207-18. doi: 10.1038/npp.2015.231

47. Wei D, Au Yeung SL, Lu M, Xiao W, Lu J, Shen S, et al. Association between prenatal depressive symptoms and eczema in infants: the born in Guangzhou Cohort Study. Pediatr Allergy Immunol. (2020) 31:662-70. doi: $10.1111 /$ pai.13254

48. Chang HY, Suh DI, Yang SI, Kang MJ, Lee SY, Lee E, et al. Prenatal maternal distress affects atopic dermatitis in offspring mediated by oxidative stress. $J$ Allergy Clin Immunol. (2016) 138:468-75.e5. doi: 10.1016/j.jaci.2016.01.020

49. Van den Bergh BR, Marcoen A. High antenatal maternal anxiety is related to ADHD symptoms, externalizing problems, and anxiety in 8- and 9-year-olds. Child Dev. (2004) 75:1085-97. doi: 10.1111/j.1467-8624.2004.00727.x
50. Spann MN, Monk C, Scheinost D, Peterson BS. Maternal immune activation during the third trimester is associated with neonatal functional connectivity of the salience network and fetal to toddler behavior. J Neurosci. (2018) 38:2877. doi: 10.1523/JNEUROSCI.2272-17.2018

51. Martinez MP, Lin J, Chow T, Chung J, Wang X, Xiang AH. Maternal gestational diabetes and type 2 diabetes during pregnancy and risk of childhood asthma in offspring. J Pediatr. (2020) 219:173-9.e1. doi: 10.1016/j.jpeds.2019.12.053

52. Liu X, Agerbo E, Li J, Dharmage SC, Thomsen RW, Olsen J, et al. Maternal pregestational or gestational diabetes and childhood wheezing: a populationbased cohort study. Allergy. (2018) 73:2247-50. doi: 10.1111/all.13551

53. Kumar R, Ouyang F, Story RE, Pongracic JA, Hong X, Wang G, et al. Gestational diabetes, atopic dermatitis, and allergen sensitization in early childhood. J Allergy Clin Immunol. (2009) 124:1031-8.e84. doi: 10.1016/j.jaci.2009.06.052

54. Gardener H, Spiegelman D, Buka SL. Prenatal risk factors for autism: comprehensive meta-analysis. Br J Psychiatry. (2009) 195:7-14. doi: 10.1192/bjp.bp.108.051672

55. Xiang AH, Wang X, Martinez MP, Page K, Buchanan TA, Feldman RK. Maternal type 1 diabetes and risk of autism in offspring. JAMA. (2018) 320:89-91. doi: 10.1001/jama.2018.7614

56. Pantham PI, Aye LMH, Powell TL. Inflammation in maternal obesity and gestational diabetes mellitus. Placenta. (2015) 36:709-15. doi: 10.1016/j.placenta.2015.04.006

57. Abell SK, De Courten B, Boyle JA, Teede HJ. Inflammatory and other biomarkers: role in pathophysiology and prediction of gestational diabetes mellitus. Int J Mol Sci. (2015) 16:13442-73. doi: 10.3390/ijms160613442

58. Darwish AH, Elgohary TM, Nosair NA. Serum interleukin-6 level in children with attention-deficit hyperactivity disorder (ADHD). J Child Neurol. (2019) 34:61-7. doi: 10.1177/0883073818809831

59. Ghaffari MA, Mousavinejad E, Riahi F, Mousavinejad M, Afsharmanesh MR. Increased serum levels of tumor necrosis factor-alpha, resistin, and visfatin in the children with autism spectrum disorders: a case-control study. Neurol Res Int. (2016) 2016:9060751. doi: 10.1155/2016/9060751

60. Xie J, Huang L, Li X, Li H, Zhou Y, Zhu H, et al. Immunological cytokine profiling identifies TNF- $\alpha$ as a key molecule dysregulated in autistic children. Oncotarget. (2017) 8:82390-8. doi: 10.18632/oncotarget.19326

61. Aral M, Arican O, Gul M, Sasmaz S, Kocturk SA, Kastal U, et al. The relationship between serum levels of total IgE, IL-18, IL-12, IFN-gamma and disease severity in children with atopic dermatitis. Media Inflamm. (2006) 2006:73098. doi: 10.1155/MI/2006/73098

62. Flom J, Cowell W, Rosa MJ, Ganguri H, Chiu YHM, Kannan S, et al. Associations between active maternal atopy in pregnancy and offspring asthma risk: effect modification by prenatal dietary long-chain polyunsaturated fatty acid intake. J Allergy Clin Immunol. (2020) 145(Suppl. 2):AB162. doi: 10.1016/j.jaci.2019.12.428

63. Martel MJ, Beauchesne MF, Malo JL, Rey E, Perreault S, Forget A, et al. Maternal asthma, its control and severity in pregnancy, and the incidence of atopic dermatitis and allergic rhinitis in the offspring. J Pediatr. (2009) 155:707-13.e1. doi: 10.1016/j.jpeds.2009.05.004

64. Soto-Quiros ME, Silverman EK, Hanson LA, Weiss ST, Celedón JC. Maternal history, sensitization to allergens current wheezing rhinitis, and eczema among children in Costa Rica. Pediatr Pulmonol. (2002) 33:237-43. doi: $10.1002 /$ ppul.10070

65. Instanes JT, Halmøy A, Engeland A, Haavik J, Furu K, Klungsøyr K. Attention-deficit/hyperactivity disorder in offspring of mothers with inflammatory and immune system diseases. Biol Psychiatry. (2017) 81:452-9. doi: 10.1016/j.biopsych.2015.11.024

66. Croen LA, Grether JK, Yoshida CK, Odouli R, Van de Water J. Maternal autoimmune diseases, asthma and allergies, and childhood autism spectrum disorders: a case-control study. Arch Pediatr Adolesc Med. (2005) 159:151-7. doi: 10.1001/archpedi.159.2.151

67. Mikhaylova L, Zhang Y, Kobzik L, Fedulov AV. Link between epigenomic alterations and genome-wide aberrant transcriptional response to allergen in dendritic cells conveying maternal asthma risk. PLoS ONE. (2013) 8:e70387. doi: 10.1371/journal.pone.0070387

68. Liu X, Agerbo E, Schlünssen V, Wright RJ, Li J, Munk-Olsen T. Maternal asthma severity and control during pregnancy and risk of offspring asthma. 
J Allergy Clin Immunol. (2018) 141:886-92.e3. doi: 10.1016/j.jaci.2017. 05.016

69. Clifton VL, Murphy VE. Maternal asthma as a model for examining fetal sex-specific effects on maternal physiology and placental mechanisms that regulate human fetal growth. Placenta. (2004) 25(Suppl. A):S45-52. doi: 10.1016/j.placenta.2004.01.004

70. Cowell WJ, Bellinger DC, Wright RO, Wright RJ. Antenatal active maternal asthma and other atopic disorders is associated with ADHD behaviors among school-aged children. Brain Behav Immun. (2019) 80:8718. doi: 10.1016/j.bbi.2019.05.040

71. Skypala I, Vlieg-Boerstra B. Food intolerance and allergy: increased incidence or contemporary inadequate diets? Curr Opin Clin Nutr Metab Care. (2014) 17:442-7. doi: 10.1097/MCO.0000000000000086

72. Julia V, Macia L, Dombrowicz D. The impact of diet on asthma and allergic diseases. Nat Rev Immunol. (2015) 15:308-22. doi: 10.1038/nri3830

73. Wang LJ, Yang CY, Chou WJ, Lee MJ, Chou MC, Kuo HC, et al. Gut microbiota and dietary patterns in children with attentiondeficit/hyperactivity disorder. Eur Child Adolesc Psychiatry. (2020) 29:287-97. doi: 10.1007/s00787-019-01352-2

74. Howard AL, Robinson M, Smith GJ, Ambrosini GL, Piek JP, Oddy WH. ADHD is associated with a "Western" dietary pattern in adolescents. J Atten Disord. (2010) 15:403-11. doi: 10.1177/1087054710365990

75. Noble EE, Hsu TM, Kanoski SE. Gut to brain dysbiosis: mechanisms linking western diet consumption, the microbiome, cognitive impairment. Front Behav Neurosci. (2017) 11:9. doi: 10.3389/fnbeh.2017.00009

76. Hussain M, Bonilla-Rosso G, Kwong Chung CKC, Bäriswyl L, Rodriguez MP, Kim BS, et al. High dietary fat intake induces a microbiota signature that promotes food allergy. J Allergy Clin Immunol. (2019) 144:157-70.e8. doi: 10.1016/j.jaci.2019.01.043

77. Wu JZ, Ge DD, Zhou LF, Hou LY, Zhou Y, Li QY. Effects of particulate matter on allergic respiratory diseases. Chronic Dis Transl Med. (2018) 4:95-102. doi: 10.1016/j.cdtm.2018.04.001

78. Morgenstern V, Zutavern A, Cyrys J, Brockow I, Koletzko S, Krämer U, et al. Atopic diseases, allergic sensitization, and exposure to traffic-related air pollution in children. Am J Respir Crit Care Med. (2008) 177:1331-7. doi: 10.1164/rccm.200701-036OC

79. Brauer M, Hoek G, Van Vliet P, Meliefste K, Fischer PH, Wijga A, et al. Air pollution from traffic and the development of respiratory infections and asthmatic and allergic symptoms in children. Am J Respir Crit Care Med. (2002) 166:1092-8. doi: 10.1164/rccm.200108-007OC

80. Kim B-J, Hong S-J. Ambient air pollution and allergic diseases in children. Korean J Pediatr. (2012) 55:185-92. doi: 10.3345/kjp.2012.55.6.185

81. Kim KN, Bae S, Park HY, Kwon HJ, Hong YC. Low-level mercury exposure and risk of asthma in school-age children. Epidemiology. (2015) 26:733-9. doi: 10.1097/EDE.0000000000000351

82. Shin J, Kim BM, Ha M, Park HS, Hong YC, Kim Y, et al. The association between mercury exposure and atopic dermatitis in early childhood: a mothers and children's environmental health study. Epidemiology. (2019) 30:S3-8. doi: 10.1097/EDE.00000000000 01002

83. Myhre O, Låg M, Villanger GD, Oftedal B, Øvrevik J, Holme JA, Aase H, et al. Early life exposure to air pollution particulate matter (PM) as risk factor for attention deficit/hyperactivity disorder (ADHD): need for novel strategies for mechanisms and causalities. Toxicol Appl Pharmacol. (2018) 354:196-214. doi: 10.1016/j.taap.2018.03.015

84. Saez M, Barceló MA, Farrerons M, López-Casasnovas G. The association between exposure to environmental factors and the occurrence of attention-deficit/hyperactivity disorder (ADHD). a populationbased retrospective cohort study. Environ Res. (2018) 166:205-14. doi: 10.1016/j.envres.2018.05.009

85. Ye BS, Leung AOW, Wong MH. The association of environmental toxicants and autism spectrum disorders in children. Environ Pollut. (2017) 227:23442. doi: 10.1016/j.envpol.2017.04.039

86. Windham GC, Zhang L, Gunier R, Croen LA, Grether JK. Autism spectrum disorders in relation to distribution of hazardous air pollutants in the San Francisco bay area. Environ Health Perspect. (2006) 114:1438-44. doi: 10.1289/ehp. 9120
87. Zheng H, Liang H, Wang Y, Miao M, Shi T, Yang F, et al. Altered gut microbiota composition associated with eczema in infants. PLOS ONE. (2016) 11:e0166026. doi: 10.1371/journal.pone.0166026

88. Cenit MC, Nuevo IC, Codoñer-Franch P, Dinan TG, Sanz Y. Gut microbiota and attention deficit hyperactivity disorder: new perspectives for a challenging condition. Eur Child Adolesc Psychiatry. (2017) 26:1081-92. doi: 10.1007/s00787-017-0969-z

89. Zijlmans MA, Korpela K, Riksen-Walraven JM, de Vos WM, de Weerth C. Maternal prenatal stress is associated with the infant intestinal microbiota. Psychoneuroendocrinology. (2015) 53:233-45. doi: 10.1016/j.psyneuen.2015.01.006

90. Bundgaard-Nielsen C, Knudsen J, Leutscher PDC, Lauritsen MB, Nyegaard M, Hagstrøm S, et al. Gut microbiota profiles of autism spectrum disorder and attention deficit/hyperactivity disorder: a systematic literature review. Gut Microbes. (2020) 11:1172-87. doi: 10.1080/19490976.2020.1748258

91. Simonyté Sjödin K, Hammarström ML, Rydén P, Sjödin A, Hernell O, Engstrand L, et al. Temporal and long-term gut microbiota variation in allergic disease: A prospective study from infancy to school age. Allergy. (2019) 74:176-85. doi: 10.1111/all.13485

92. Carlson AL, Xia K, Azcarate-Peril MA, Goldman BD, Ahn M, Styner MA, et al. Infant gut microbiome associated with cognitive development. Biol Psychiatry. (2017) 83:148-59. doi: 10.1016/j.biopsych.2017.06.021

93. Szopinska-Tokov J, Dam S, Naaijen J, Konstanti P, Rommelse N, Belzer $\mathrm{C}$, et al. Investigating the gut microbiota composition of individuals with attention-deficit/hyperactivity disorder and association with symptoms. Microorganisms. (2020) 8:406. doi: 10.3390/microorganisms8030406

94. Prehn-Kristensen A, Zimmermann A, Tittmann L, Lieb W, Schreiber S, Baving $\mathrm{L}$, et al. Reduced microbiome alpha diversity in young patients with ADHD. PLoS ONE. (2018) 13:e0200728. doi: 10.1371/journal.pone.0200728

95. Zimmermann P, Messina N, Mohn WW, Finlay BB, Curtis N. Association between the intestinal microbiota and allergic sensitization, eczema, and asthma: a systematic review. J Allergy Clin Immunol. (2019) 143:467-85. doi: 10.1016/j.jaci.2018.09.025

96. Wang H, Li Y, Feng X, Li Y, Wang W, Qiu C, et al. Dysfunctional gut microbiota and relative co-abundance network in infantile eczema. Gut Pathog. (2016) 8:36. doi: 10.1186/s13099-016-0118-0

97. Ramirez FD, Chen S, Langan SM, Prather AA, McCulloch CE, Kidd SA, et al. Association of atopic dermatitis with sleep quality in children. JAMA Pediatr. (2019) 173:e190025. doi: 10.1001/jamapediatrics.2019.0025

98. Bender BG, Ballard R, Canono B, Murphy JR, Leung DY. Disease severity, scratching, and sleep quality in patients with atopic dermatitis. J Am Acad Dermatol. (2008) 58:415-20. doi: 10.1016/j.jaad.2007.10.010

99. Anuntaseree W, Sangsupawanich P, Osmond C, Mo-Suwan L, Vasiknanonte P, Choprapawon C. Sleep quality in infants with atopic dermatitis: a community-based, birth cohort study. Asian Pacific J Allergy Immunol. (2012) 30:26.

100. Kan K, Gupta RS. Association of atopic dermatitis with sleep quality in children. Pediatrics. (2019) 144:S22. doi: 10.1542/peds.2019-2461FF

101. Chang HY, Seo JH, Kim HY, Kwon JW, Kim BJ, Kim HB, et al. Allergic diseases in preschoolers are associated with psychological and behavioural problems. Allergy Asthma Immunol Res. (2013) 5:315-21. doi: 10.4168/aair.2013.5.5.315

102. Romanos M, Gerlach M, Warnke A, Schmitt J. Association of attentiondeficit/hyperactivity disorder and atopic eczema modified by sleep disturbance in a large population-based sample. J Epidemiol Community Health. (2010) 64:269-73. doi: 10.1136/jech.2009.093534

103. Molfese DL, Ivanenko A, Key AF, Roman A, Molfese VJ, O'Brien LM, et al. A one-hour sleep restriction impacts brain processing in young children across tasks: Evidence from event-related potentials. Dev Neuropsychol. (2013) 38:317-36. doi: 10.1080/87565641.2013.799169

104. Chen K, Zheng X, Li Z, Xiang H, Chen B, Zhang H. Risk factors analysis of attention deficit/hyperactivity disorder and allergic rhinitis in children: a cross-sectional study. Ital J Pediatr. (2019) 45:99. doi: 10.1186/s13052-019-0703-1

105. Mazurek MO, Sohl K. Sleep and behavioral problems in children with autism spectrum disorder. J Autism Dev Disord. (2016) 46:1906-15. doi: 10.1007/s10803-016-2723-7 
106. Cohen S, Conduit R, Lockley SW, Rajaratnam SM, Cornish KM. The relationship between sleep and behavior in autism spectrum disorder (ASD): A review. J Neurodev Disord. (2014) 6:44. doi: 10.1186/1866-1955-6-44

107. Murrison LB, Brandt EB, Myers JB, Hershey GKK. Environmental exposures and mechanisms in allergy and asthma development. J Clin Investig. (2019) 129:1504-15. doi: 10.1172/JCI124612

108. Rauh VA, Margolis AE. Research review: Environmental exposures, neurodevelopment, and child mental health - new paradigms for the study of brain and behavioral effects. J Child Psychol Psychiatry. (2016) 57:775-93. doi: $10.1111 /$ jcpp. 12537

109. DeVries A, Vercelli D. Epigenetics in allergic diseases. Curr Opin Pediatr. (2015) 27:719-23. doi: 10.1097/MOP.0000000000000285

110. Millan MJ. An epigenetic framework for neurodevelopmental disorders: From pathogenesis to potential therapy. Neuropharmacology. (2013) 68:282. doi: 10.1016/j.neuropharm.2012.11.015

111. Xu CJ, Söderhäll C, Bustamante M, Baïz N, Gruzieva O, Gehring U, et al. DNA methylation in childhood asthma: an epigenome-wide meta-analysis. Lancet Respirat Med. (2018) 6:379-88. doi: 10.1016/S2213-2600(18)30052-3

112. Reese SE, Xu CJ, den Dekker HT, Lee MK, Sikdar S, Ruiz-Arenas C, et al. Epigenome-wide meta-analysis of DNA methylation and childhood asthma. J Allergy Clin Immunol. (2019) 143:2062-74. doi: 10.1016/j.jaci.2018.11.043

113. van Mil NH, Steegers-Theunissen RP, Bouwland-Both MI, Verbiest MM, Rijlaarsdam J, Hofman A, et al. DNA methylation profiles at birth and child ADHD symptoms. J Psychiatr Res. (2014) 49:51-9. doi: 10.1016/j.jpsychires.2013.10.017

114. Mooney MA, Ryabinin P, Wilmot B, Bhatt P, Mill J, Nigg JT. Large epigenome-wide association study of childhood ADHD identifies peripheral DNA methylation associated with disease and polygenic risk burden. Transl Psychiatry. (2020) 10:8. doi: 10.1038/s41398-020-0710-4

115. Vogel Ciernia A, Careaga M, LaSalle JM, Ashwood P. Microglia from offspring of dams with allergic asthma exhibit epigenomic alterations in genes dysregulated in autism. Glia. (2018) 66:505-21. doi: 10.1002/glia.23261

116. Hernández-Aguilera A, Rull A, Rodríguez-Gallego E, Riera-Borrull M, Luciano-Mateo F, Camps J, et al. Mitochondrial dysfunction: a basic mechanism in inflammation-related non-communicable diseases and therapeutic opportunities. Media Inflamm. (2013) 2013:135698. doi: $10.1155 / 2013 / 135698$

117. Iyer D, Mishra N, Agrawal A. Mitochondrial function in allergic disease. Curr Allergy Asthma Rep. (2017) 17:29. doi: 10.1007/s11882-017-0695-0

118. Raby BA, Klanderman B, Murphy A, Mazza S, Camargo CAJr, Silverman $\mathrm{EK}$, et al. A common mitochondrial haplogroup is associated with elevated total serum IgE levels. J Allergy Clin Immunol. (2007) 120:351-8. doi: 10.1016/j.jaci.2007.05.029
119. Ederlé C, Charles AL, Khayath N, Poirot A, Meyer A, Clere-Jehl R, et al. Mitochondrial function in peripheral blood mononuclear cells (PBMC) is enhanced, together with increased reactive oxygen species, in severe asthmatic patients in exacerbation. J Clin Med. (2019) 8:1613. doi: $10.3390 / \mathrm{jcm} 8101613$

120. Mabalirajan U, Dinda AK, Kumar S, Roshan R, Gupta P, Sharma SK, et al. Mitochondrial structural changes and dysfunction are associated with experimental allergic asthma. J Immunol. (2008) 181:3540-8. doi: 10.4049/jimmunol.181.5.3540

121. Aguilera-Aguirre L, Bacsi A, Saavedra-Molina A, Kurosky A, Sur S, Boldogh I. Mitochondrial dysfunction increases allergic airway inflammation. J Immunol. (2009) 183:5379-87. doi: 10.4049/jimmunol.0900228

122. Chauhan A, Gu F, Essa MM, Wegiel J, Kaur K, Brown WT, et al. Brain region-specific deficit in mitochondrial electron transport chain complexes in children with autism. J Neurochem. (2011) 117:209-20. doi: 10.1111/j.1471-4159.2011.07189.x

123. Tang G, Gutierrez Rios P, Kuo SH, Akman HO, Rosoklija G, Tanji K, et al. Mitochondrial abnormalities in temporal lobe of autistic brain. Neurobiol Dis. (2013) 54:349-61. doi: 10.1016/j.nbd.2013.01.006

124. Gu F, Chauhan V, Kaur K, Brown WT, LaFauci G, Wegiel J, et al. Alterations in mitochondrial DNA copy number and the activities of electron transport chain complexes and pyruvate dehydrogenase in the frontal cortex from subjects with autism. Transl Psychiatry. (2013) 3:e299. doi: 10.1038/tp.2013.68

125. Verma P, Singh A, Nthenge-Ngumbau DN, Rajamma U, Sinha S, Mukhopadhyay $\mathrm{K}$, et al. Attention deficit-hyperactivity disorder suffers from mitochondrial dysfunction. BBA Clinical. (2016) 6:153-8. doi: 10.1016/j.bbacli.2016.10.003

126. Frye RE, Rossignol DA. Mitochondrial dysfunction can connect the diverse medical symptoms associated with autism spectrum disorders. Pediatr Res. (2011) 69:41R-7. doi: 10.1203/PDR.0b013e318212f16b

Conflict of Interest: The authors declare that the research was conducted in the absence of any commercial or financial relationships that could be construed as a potential conflict of interest.

Copyright (C) 2021 Chua, Tay, Ooi, Siah, Tham, Shek, Meaney, Broekman and Loo. This is an open-access article distributed under the terms of the Creative Commons Attribution License (CC BY). The use, distribution or reproduction in other forums is permitted, provided the original author(s) and the copyright owner(s) are credited and that the original publication in this journal is cited, in accordance with accepted academic practice. No use, distribution or reproduction is permitted which does not comply with these terms. 